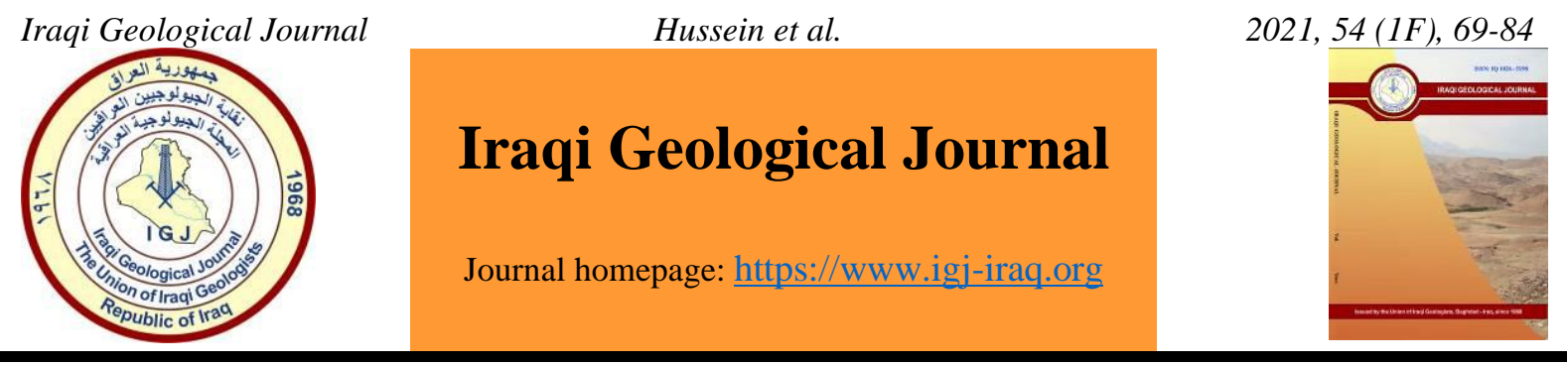

\title{
Sedimentological Properties of the Sand Dunes and Valley Sediments in Al- Muthanna, Southern Iraq
}

\author{
Mohammed L. Hussein', Mahdi A. Menshed ${ }^{2}$, Mohanad R. A. Al-Owaidi ${ }^{3, *}$ and \\ Murtada D. Abduula ${ }^{4}$ \\ 1 Department of Building and Construction Engineering Technologies, Al-Mustaqbal University College, Iraq \\ 2 Department of Geology, College of Science, University of Thi Qar, Iraq \\ 3 Department of Applied Geology, College of Science, University of Babylon, Iraq \\ 4 Oil and Gas Engineering College, Alayen University, Iraq \\ * Correspondence: sci.mohanad.rasim@uobabylon.edu.iq
}

Received: 10 April 2021; Accepted: 2 June 2021; Published: 30 June 2021

\begin{abstract}
Sedimentological properties of the dunes and valley terrigenous sediments in Al-Muthanna Governorate, southern Iraq were carried out. Ten samples were collected, where five samples from both sand dunes, and valley sediments. Grain size analysis revealed that sand, silt and clay fractions are the constituents of these sediments. Sand fractions predominant in the dunes and the texture is classified as silty sand, whereas clay fractions dominate in the valley sediments, with sandy clay texture. The mineralogy is determined by X-ray diffraction, which revealed that quartz is the main mineral in both study areas, followed by calcite, feldspars in lesser amount and evaporates (gypsum) in minor component of the light minerals. Petrographically, monocrystalline quartz dominates over polycrystalline quartz in both areas. Rock fragments in the valley sediments are higher than in the sand dunes, which are comprised of carbonate, chert, igneous, metamorphic, evaporate, and mudstone rock fragments. Feldspars are approximately similar in the study areas and comprised mainly alkali feldspar (potash feldspar) and plagioclase. Petrogenically, the sand dunes occupy the quartzose-recycled field, while the valley sediments fall in transitional recycled fields represented recycled orogeny.
\end{abstract}

Keywords: Sand dunes; Sedimentology; Mineralogy; Southern Iraq

\section{Introduction}

Sand covers $20 \%$ of the earth's deserts, while deserts cover approximately $20 \%$ of the earth's surface (Watson, 1997). The sand, which was generated by erosion of rock, containing quartz, feldspar, in addition to other hard minerals (Pye and Toser, 2009). Iraqi Mesopotamian Plain for the past four decades had been, and still, suffered from desertification, in which vast agricultural areas are transformed into sand dune fields. The valleys are among the most common Quaternary deposits in the study area. They consist of soft sedimentary deposits, or sandy and silty gravel in the main and deep valleys. In general, the thickness of these deposits is not more than one meter. It is still partially active, and the depositional environment of these sediments is riverine.

The study area is represented by the Quaternary deposits of Mesopotamian and Salman Zones particularly, of the Pleistocene and latest Holocene deposits that involve alluvial fans, valley fills, lacustrine, marsh and aeolian sediments (Jasim, 2017). Outcrops of the following formations ranging in

DOI: $10.46717 /$ igj.54.1F.7ms-2021-06-27 
age from Paleocene to Recent are existed in the area, these are Umm Er-Radhuma (Middle PaleoceneEarly Eocene), Dammam(Middle-Late Eocene), Ghar (Early Miocene), Euphrates (Middle-Late Miocene), Nfayil (Late Miocene), and Zahra (Pleistocene) (Fig. 1).

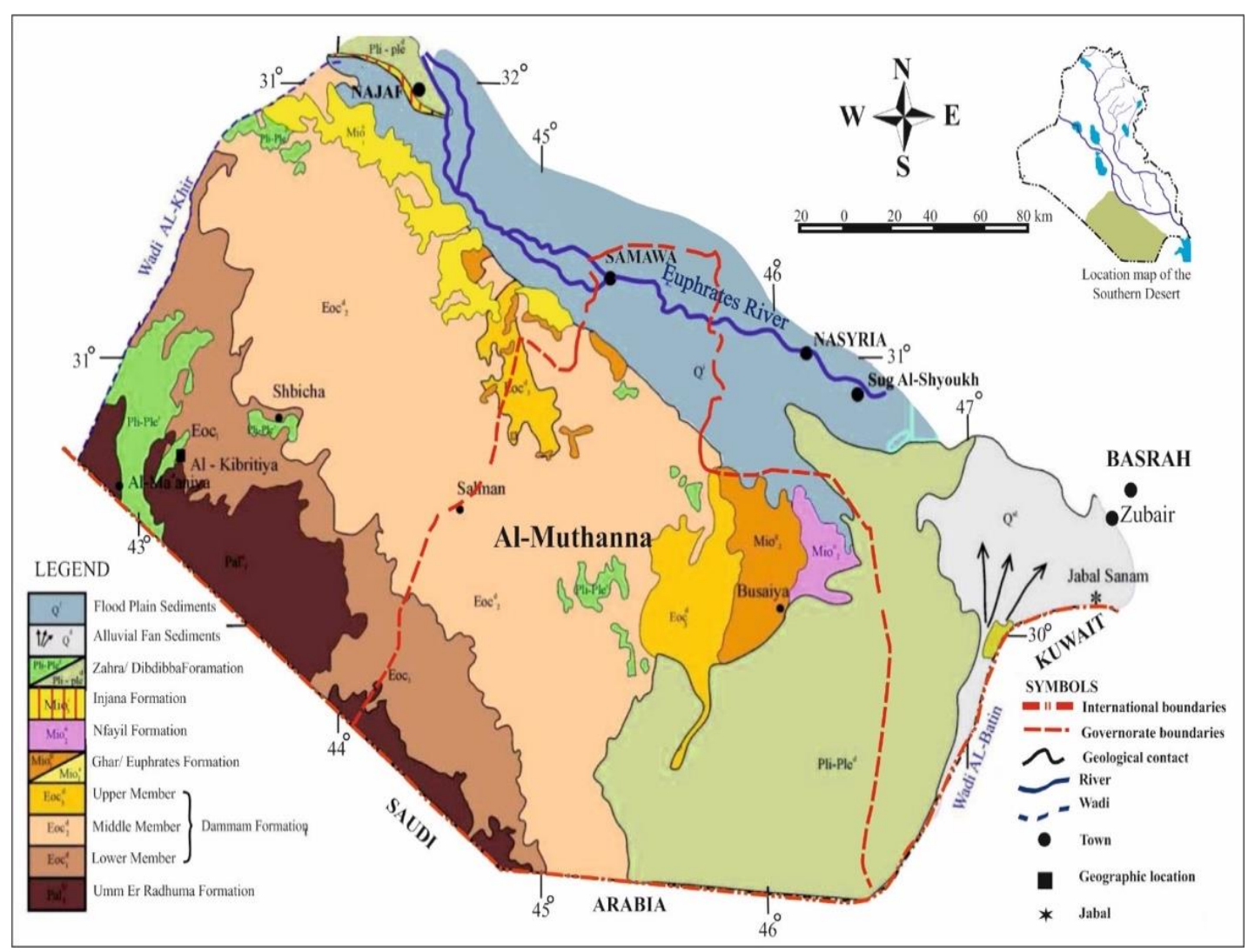

Fig. 1. Geological map of Southern Desert, Iraq (after Sissakian, 2000), showing Al-Muthanna boundaries

Tectonically, the Mesopotamian Zone is the eastern most unit of the Mesopotamian Zone in Unstable Shelf and Salman Zone in Stable Shelf. It is bordered in the northeast by the folded margins of Peshti-Kuh in the east, and Himreen and Makhul in the north. The southwest boundary is controlled by faults. The zone was probably uplifted during the Hercynian deformation, but it subsided from late Permian time onwards (Buday and Jassim, 1987). Climate conditions such as temperature, precipitation, wind strength and direction, as well dust storms, all of which affect the availability of sediment and its ability to be transported by aeolian processes (Lancaster, 1995; Rasheed and Al-Ramahi, 2021). Iraq is located in an arid to a semi-arid area where the dominant continental climate is typically cold in winter and hot in summer, which is characterized by limited rainfall, a high evaporation rate, and water scarcity. Geomorphologically, several types of dunes can be observed in the study area, such as barchanoid ridges, nabkhes, and sand sheets including various types of sedimentary structures, such as cross stratification and lamination, ripple marks, burrows and borings (Fig. 2). General geological survey and other investigations of these areas had been studied by many authors such as, Buday and Jassim (1987), Al-Janabi et al. (1988), Hassan et al. (1995), Al-Shakeri, et al. (2017), Jassim (2017). Most of these studies focused on geological overviews of the study areas, and/or provided descriptions of its provenance, sedimentology, and depositional environments of sand dunes. The present work aims to shed light on the sedimentological characters of the sand dunes and valley deposits at Al-Muthanna Governorate based on grain size analysis and mineralogical analysis. 

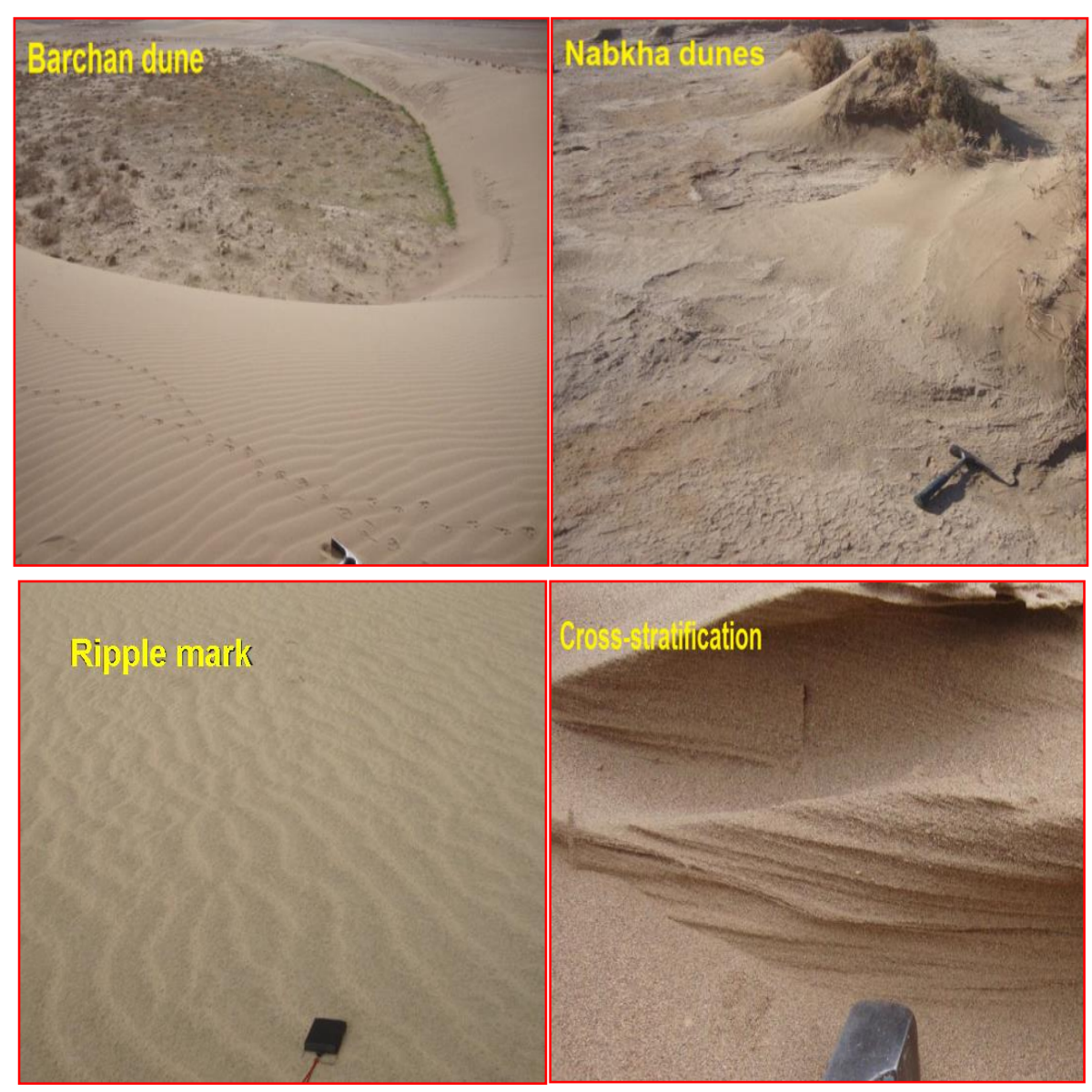

Fig. 2. Some dune types and sedimentary structure observed in the study area

\section{Materials and Methods}

In the present study, two areas are chosen at Al-Muthanna; one represents dune fields in the northern to northeastern parts between latitude $31^{\circ} 10^{\prime} 18^{\prime \prime}-30^{\circ} 17^{\prime} 52^{\prime \prime}$ and longitude $45^{\circ} 14^{\prime} 39^{\prime \prime}-$ $46^{\circ} 32^{\prime} 54^{\prime \prime}$. The other area is represented valley sediments at southern to southwestern parts between latitude $29^{\circ} 23^{\prime} 48^{\prime \prime}-30^{\circ} 25^{\prime} 43^{\prime \prime}$, and longitude $44^{\circ} 43^{\prime} 03^{\prime \prime}-44^{\circ} 42^{\prime} 27^{\prime \prime}$ (Table 1 and Fig. 3). Representative samples are collected from the studied areas, using GPS device (Geographical Position System) to determine the sites of samples. Five samples were chosen from the sand dunes, and five samples were collected from the valley filling sediments. Symbols S and D refer to samples of sand dunes and valley sediments, respectively.

Table 1. Coordinates of the study areas

\begin{tabular}{lll}
\hline Sample No. & Longitude(N) & Latitude $(\mathrm{E})$ \\
\hline S1 & $31^{\circ} 10^{\prime} 18^{\prime \prime}$ & $45^{\circ} 14^{\prime} 39^{\prime \prime}$ \\
S2 & $31^{\circ} 01^{\prime} 54^{\prime \prime}$ & $45^{\circ} 29^{\prime} 53^{\prime \prime}$ \\
S3 & $30^{\circ} 53^{\prime} 21^{\prime \prime}$ & $45^{\circ} 35^{\prime} 20^{\prime \prime}$ \\
S4 & $30^{\circ} 34^{\prime} 44^{\prime \prime}$ & $46^{\circ} 09^{\prime} 00^{\prime \prime}$ \\
S 5 & $30^{\circ} 17^{\prime} 52^{\prime \prime}$ & $46^{\circ} 32^{\prime} 54^{\prime \prime}$ \\
D1 & $29^{\circ} 23^{\prime} 48^{\prime \prime}$ & $44^{\circ} 43^{\prime} 03^{\prime \prime}$ \\
D2 & $29^{\circ} 29^{\prime} 08^{\prime \prime}$ & $44^{\circ} 50^{\prime} 01^{\prime \prime}$ \\
D3 & $29^{\circ} 52^{\prime} 40^{\prime \prime}$ & $44^{\circ} 55^{\prime} 09^{\prime \prime}$ \\
D4 & $29^{\circ} 57^{\prime} 07^{\prime \prime}$ & $44^{\circ} 46^{\prime} 27^{\prime \prime}$ \\
D5 & $30^{\circ} 25^{\prime} 43^{\prime \prime}$ & $44^{\circ} 42^{\prime} 27^{\prime \prime}$ \\
\hline
\end{tabular}




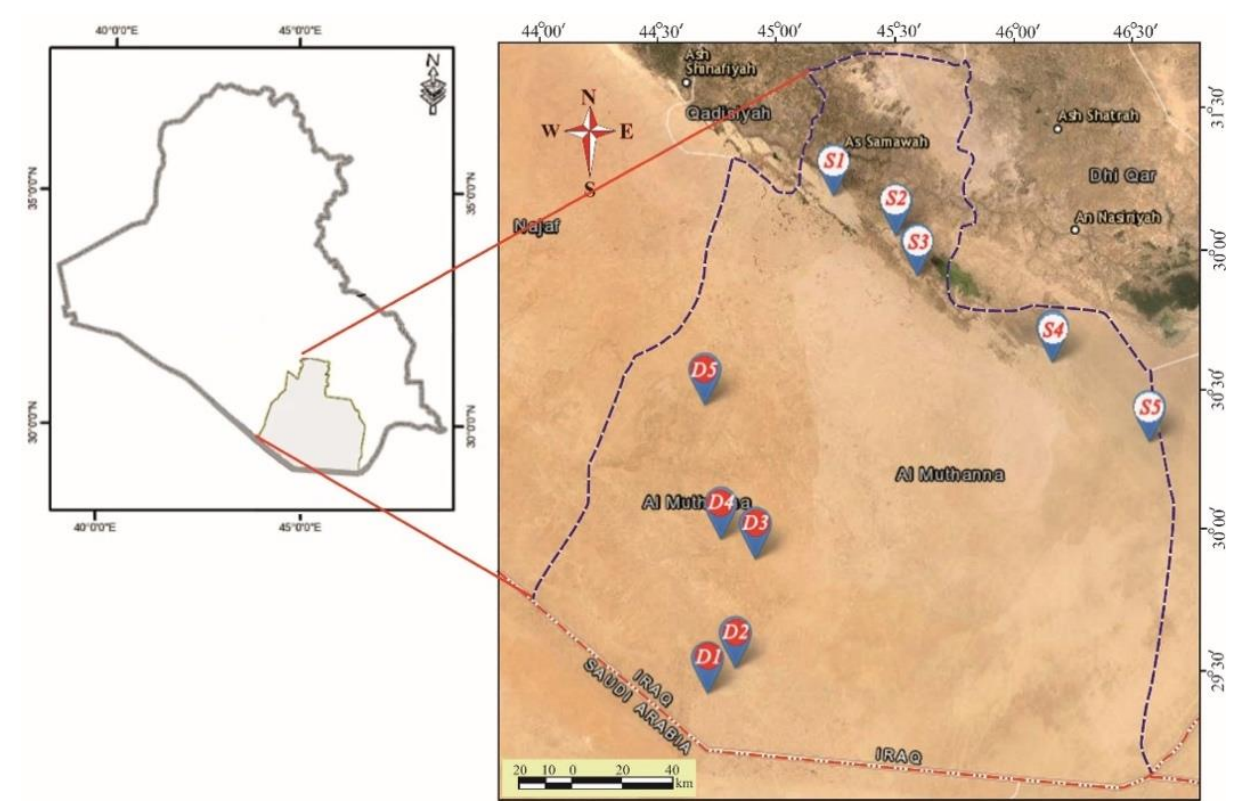

Fig. 3. Location map of the study area showing investigated sites

The collected samples were prepared in the Applied Geology Department in the College of Science, University of Babylon to examine grain size analysis according to the scale of Wentworth (1922) used by Folk (1980). The investigated samples are sized into sand, silt and clay through sieved them to separate sand $(2 \mathrm{~mm}-63 \mu \mathrm{m})$ from mud fractions, and then analyzed mud by wet method using pipette (settling tube analysis) to separate clay of $3.9 \mu \mathrm{m}$ from silt of $63 \mu \mathrm{m}$ (Allen, 1981). Identification of mineralogical specifications of sediments has been performed to determine their source, description of their properties, and their economic importance (Del Valle et al., 2008). The selected samples are provided to examine by X-ray diffraction (XRD) tool.This technique deals with the mineralogical composition of samples as a bulk to identify light minerals by choosing six samples (three of them for each study area). The processes followed are according to Thorez (1976). This technique was achieved in the XRD laboratory at the Ministry of Science and Technology. X-ray Diffractometer type is Shimadzu 6000 (Japan) under the following specifications: Target: Cu, Power: $60 \mathrm{kV}$, Current: $80 \mathrm{~mA}$, Speed: $5 \mathrm{deg} / \mathrm{min}$, Filter: Ni.

To analyze the chosen samples petrographically, under a transmitted polarized microscope, light minerals were separated from heavy minerals according to Carver (1971), as well as Mange and Maurer (1992). The separation was done by using heavy liquid (bromoform of a specific weight 2.9 for 10gms) sand fractions of grain size from 0.0625 to $0.250 \mathrm{~mm}$ in the Applied Geology Department, University of Babylon. Ten samples selected for this purpose, where five of them for each study area.

\section{Results}

\subsection{Grain Size Analysis}

Ten selective samples were collected; five from the dunes, and five from the valley filling sediments as shown in Table 2. Grain size analysis is done according to Folk (1980). Sand fractions in the sand dune samples range from $74.37 \%-85.51 \%$, with an average of $83.16 \%$ (Table 2, Figs. 4 , and 5). The main ratio of very fine grains is $63.28 \%$, fine grains $16.6 \%$, medium grains $7.78 \%$, coarse grains $0.06 \%$, respectively, with absence of very coarse grain fractions. Silt fractions range is $8.9 \%$ and $19.83 \%$ with 
a mean of $14 \%$, whereas, clay fractions range from $0.7 \%$ to $5.9 \%$ with a mean of $2.84 \%$ (Table 2 and Fig. 6). The texture of the sand dune sediments in this area according to ternary diagram of Folk (1980) is silty sand (Fig. 7).

Table 2. Grain size distribution of particles and texture sediments in the study areas

\begin{tabular}{|c|c|c|c|c|c|c|c|c|c|}
\hline \multirow{3}{*}{$\begin{array}{l}\text { Sam. } \\
\text { No. }\end{array}$} & \multicolumn{4}{|c|}{ Sand fractions (\%) } & \multirow{2}{*}{\multicolumn{2}{|c|}{$\begin{array}{c}\sum \text { sand } \\
2-0.063 \\
\mathrm{~mm}\end{array}$}} & \multirow{2}{*}{$\begin{array}{c}\text { Silt } \\
0.063-0.004 \\
\mathrm{~mm}\end{array}$} & \multirow{2}{*}{$\begin{array}{c}\text { Clay } \\
\begin{array}{c}0.004-0.001 \\
\mathrm{~mm}\end{array}\end{array}$} & \multirow{3}{*}{ Texture } \\
\hline & $\begin{array}{c}\text { V.C } \\
2-1 \mathrm{~mm}\end{array}$ & $\begin{array}{c}C \\
1-0.5 \mathrm{~mm}\end{array}$ & $\begin{array}{c}\mathrm{M} \\
0.5-0.250 \\
\mathrm{~mm}\end{array}$ & $\begin{array}{c}\mathrm{F} \\
0.250-0.225 \\
\mathrm{~mm}\end{array}$ & & & & & \\
\hline & $(-1)-0 \mathrm{phi}$ & $0-1$ phi & $1-2 \mathrm{phi}$ & 2-3 phi & 3-4 phi & $(-1)-4$ & 4-8 phi & 8-10 phi & \\
\hline S1 & 0 & 0 & 0.01 & 4.08 & 81.42 & 85.51 & 13.79 & 0.7 & Silty sand \\
\hline $\mathrm{S} 2$ & 0 & 0 & 0.1 & 10 & 80 & 90.1 & 8.9 & 1 & Sand \\
\hline S3 & 0 & 0 & 0.11 & 14.25 & 72.89 & 87.25 & 11.96 & 0.79 & Silty sand \\
\hline S4 & 0 & 0.05 & 8.41 & 27.51 & 42.72 & 78.59 & 15.51 & 5.9 & Silty sand \\
\hline S5 & 0 & 0.06 & 7.78 & 27.16 & 39.37 & 74.37 & 19.83 & 5.8 & Silty sand \\
\hline Ave. & 0 & 0.02 & 3.28 & 16.6 & 63.28 & 83.16 & 14 & 2.84 & \\
\hline D1 & 1.41 & 1.36 & 2.52 & 6.45 & 8.85 & 20.68 & 5.72 & 73.6 & Sandy clay \\
\hline D2 & 2.5 & 2.43 & 5.26 & 12.81 & 14.61 & 37.61 & 8.02 & 54.37 & Sandy clay \\
\hline D3 & 4.5 & 4.81 & 7.15 & 9.3 & 10.83 & 37.59 & 11.8 & 50.61 & Sandy clay \\
\hline D4 & 3.3 & 4.63 & 7.65 & 11.26 & 11.21 & 38.05 & 11.55 & 50.4 & Sandy clay \\
\hline D5 & 2.9 & 4.51 & 8.88 & 11.52 & 12.4 & 34.66 & 10.95 & 48.8 & Sandy clay \\
\hline Ave. & 2.92 & 3.55 & 6.29 & 10.27 & 11.58 & 33.72 & 9.61 & 55.55 & \\
\hline
\end{tabular}

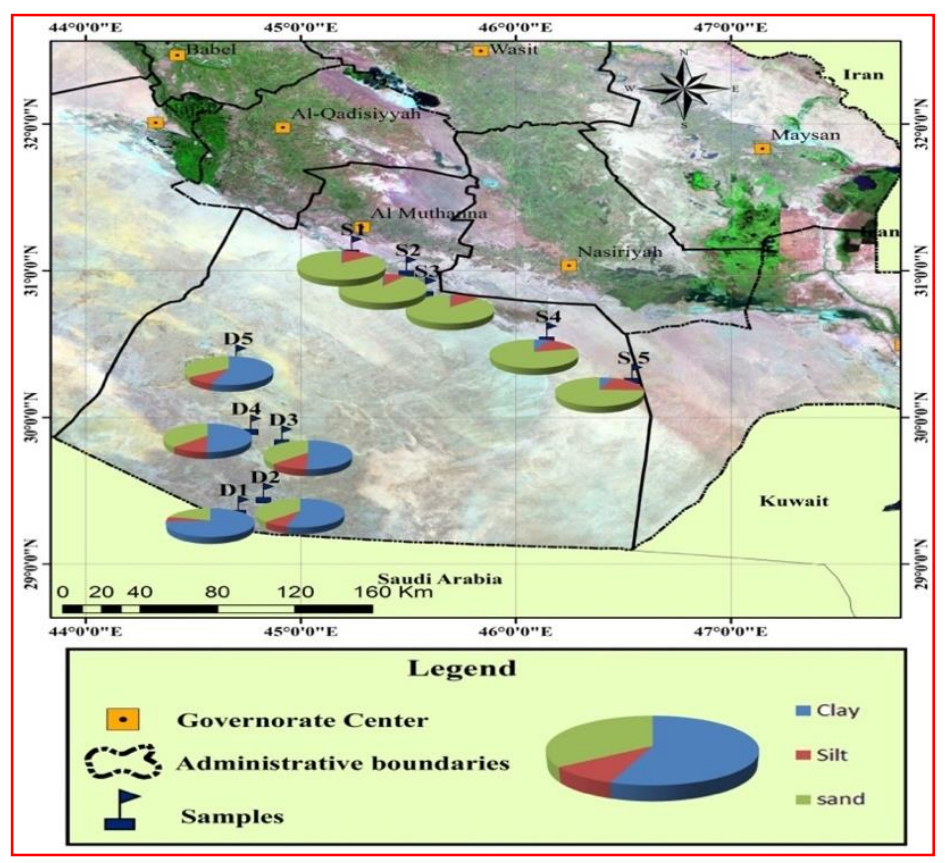

Fig. 4.The location of the selected samples showing grain size analysis in the study areas 
The valley sediments are characterized by a concentration of sand fractions in a range of $20.60 \%$ to $38.05 \%$, with a mean of $33.72 \%$. The mean ratio of very fine grains is $11.58 \%$, fine grains is $10.27 \%$, medium grains is 6.29 , coarse grains is $3.55 \%$, and very coarse grains is $2.92 \%$. Silt fractions range between $5.72 \%$ and $11.8 \%$, while clay fraction between $48.8 \%$ and $73.6 \%$ (Table 2 and Figs. 4, 5, and 6). The determined texture of the valley sediments due to Folk (1980) is sandy clay (Fig. 7). Based on graphical representation of grain size analysis data (Tucker, 1988), the unimodal mode is the prominent type present in both study areas, where very fine sand is the predominant size in the dune fields among other uncohesive particles, whilst clays represent the prevalent grains in the valley clastic sediments as in Fig. 8.

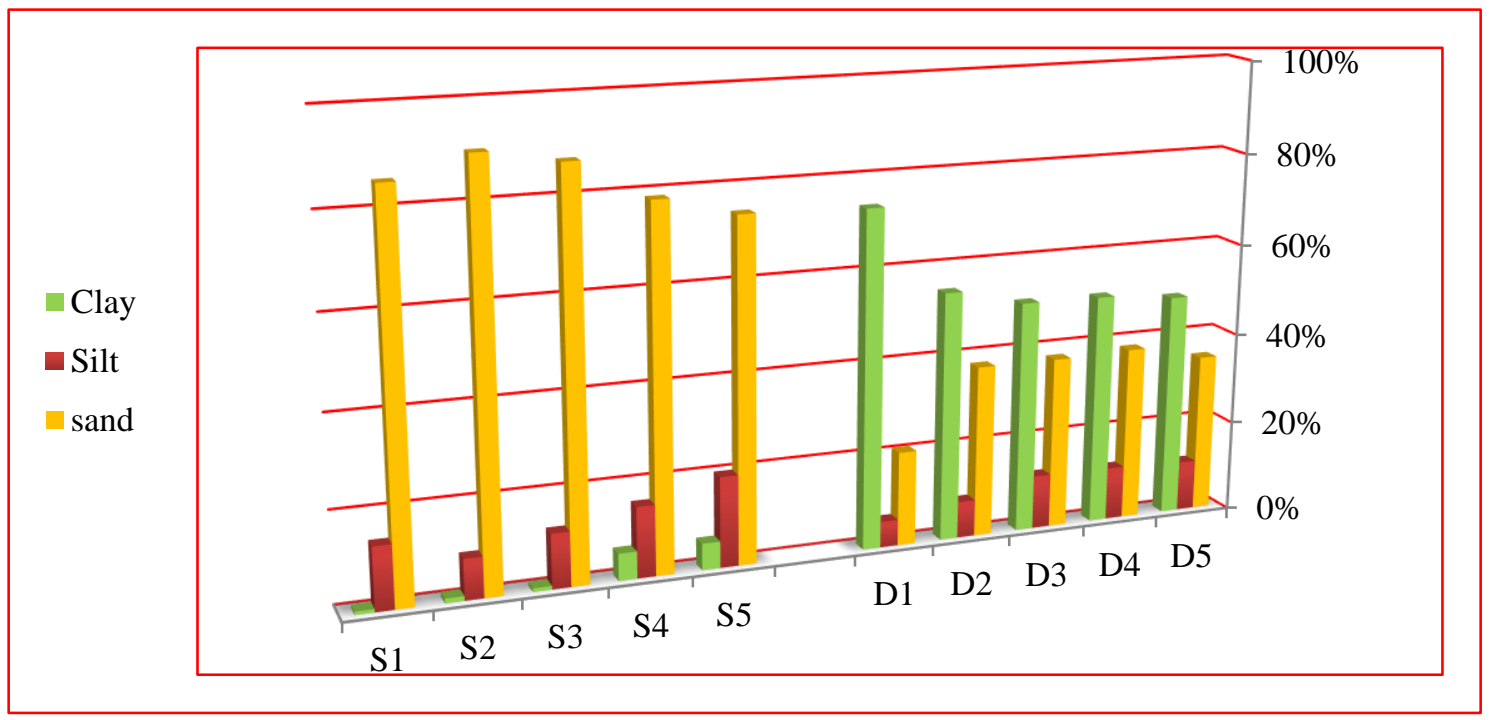

Fig. 5. Distribution of the grain size analysis in the present study.

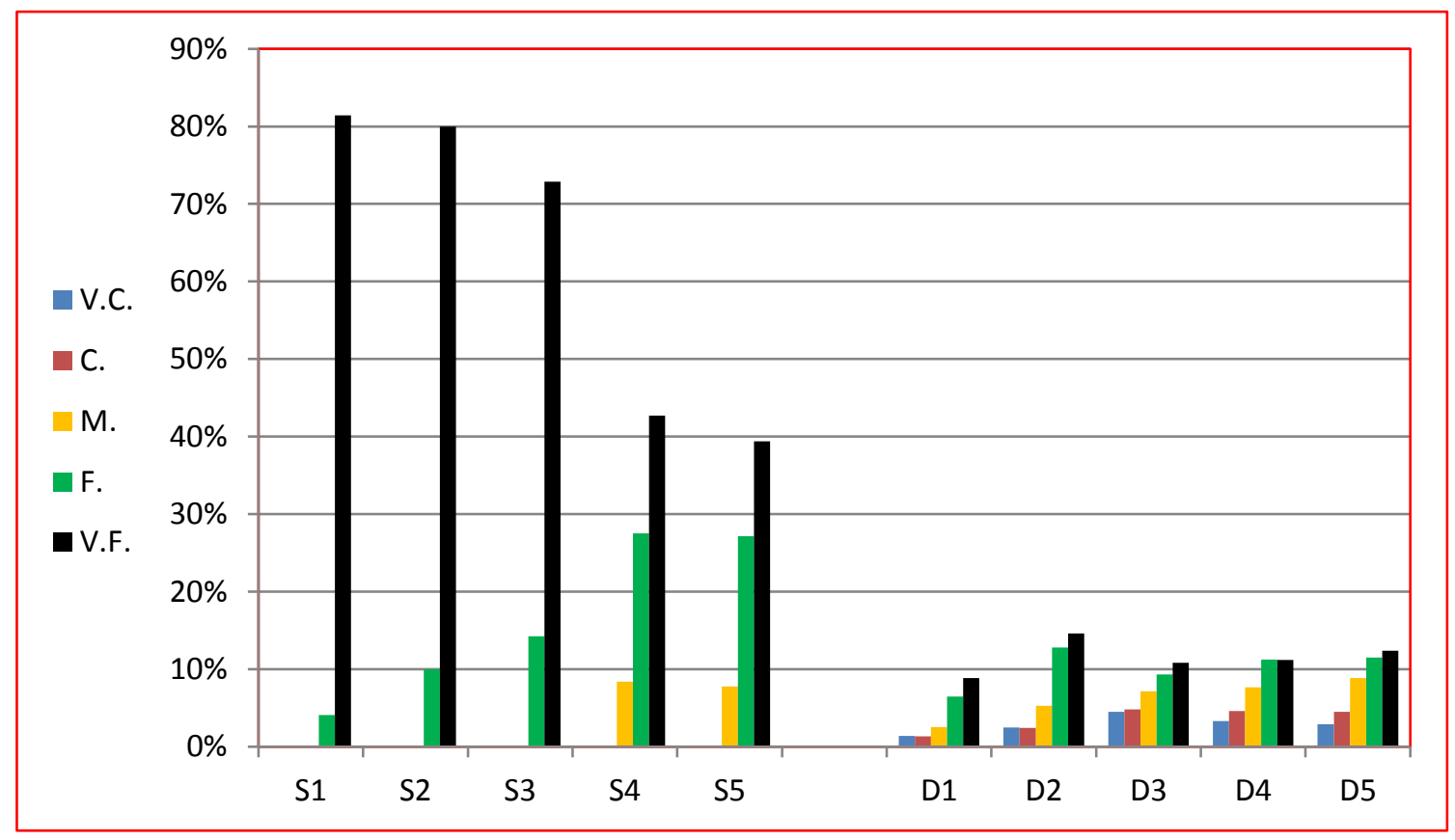

Fig. 6. Distribution of the sand fractions in the current study, where V.C: very coarse sand, C: coarse, M: medium, F: fine, V.F: very fine 


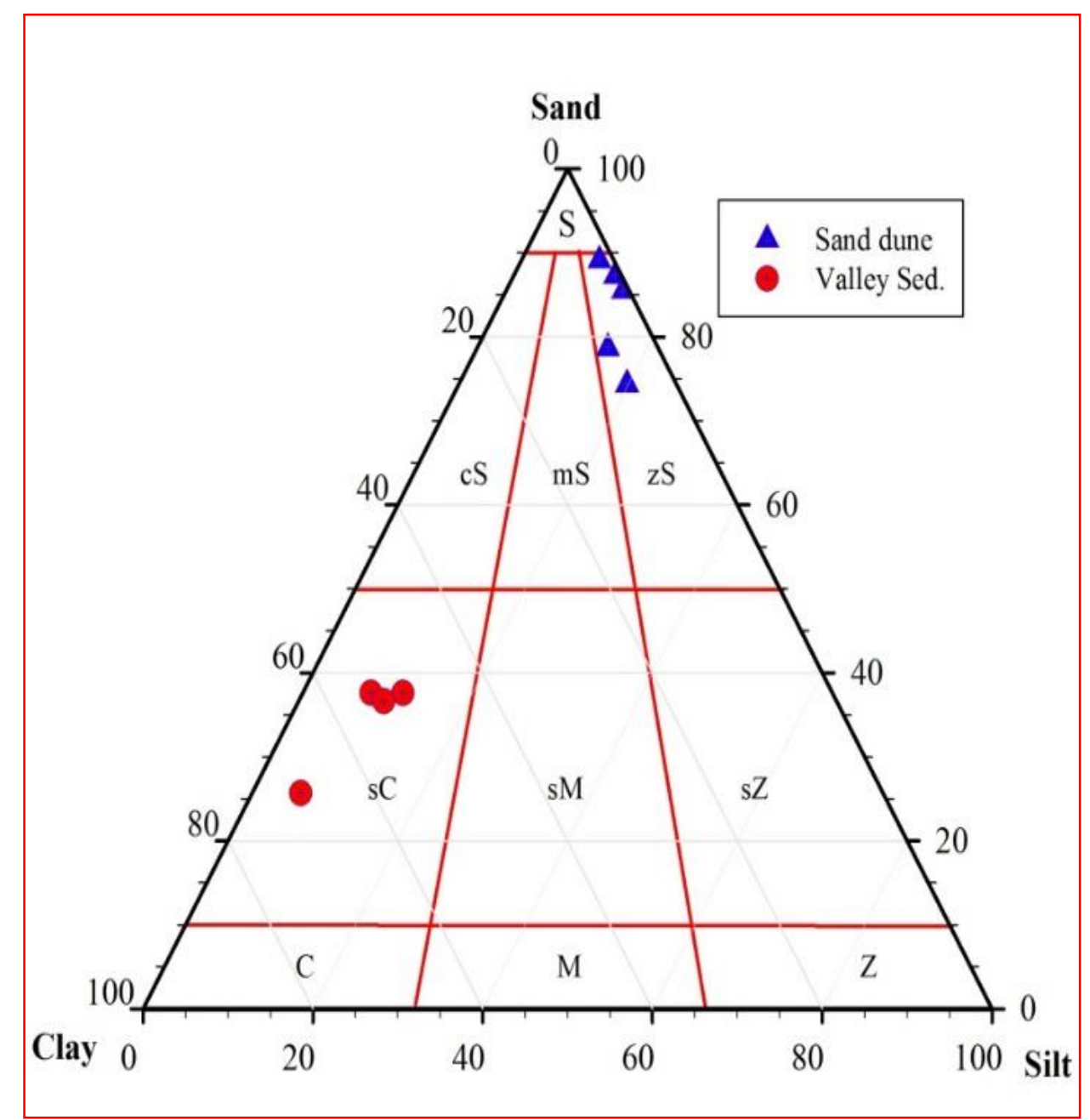

Fig. 7. Ternary diagram showing the studied samples (after Folk, 1980).
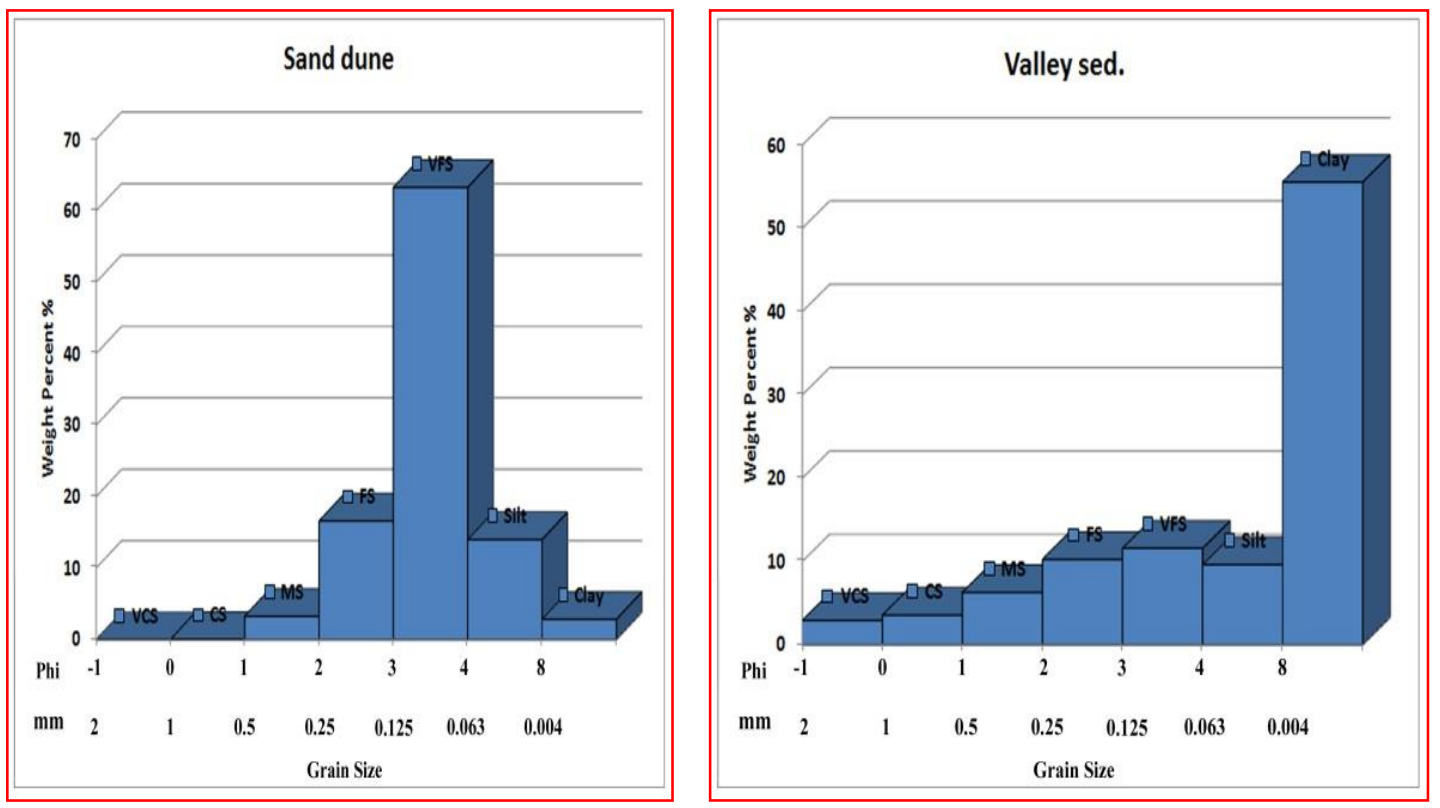

Fig. 8. Histograms showing unimodal mode of grain size statistical distribution for both studied areas. 
Sagoe and Visher (1977) suggested that the depositional environment could be interpreted based on the shape of grain-size cumulative curves plotted on log probability paper. However, sediment from different environments (dune, fluvial, beach, tidal, nearshore, and turbidities) could be differentiated based on the general shapes of the cumulative curves (Boggs, 1995). Frequency cumulative curves, show that the sand dune particles at samples S4 and S5 are recognized by grain sizes range from coarse sand to mud (0 to more than 4 phi ), whereas samples S1,S2 and S3 are characterized by grain sizes range from medium sand to mud (1 to more than 4 phi). The valley sediment grains recorded very coarse to mud size in all samples (-1 to more than 4 phi) as in Fig. 9.

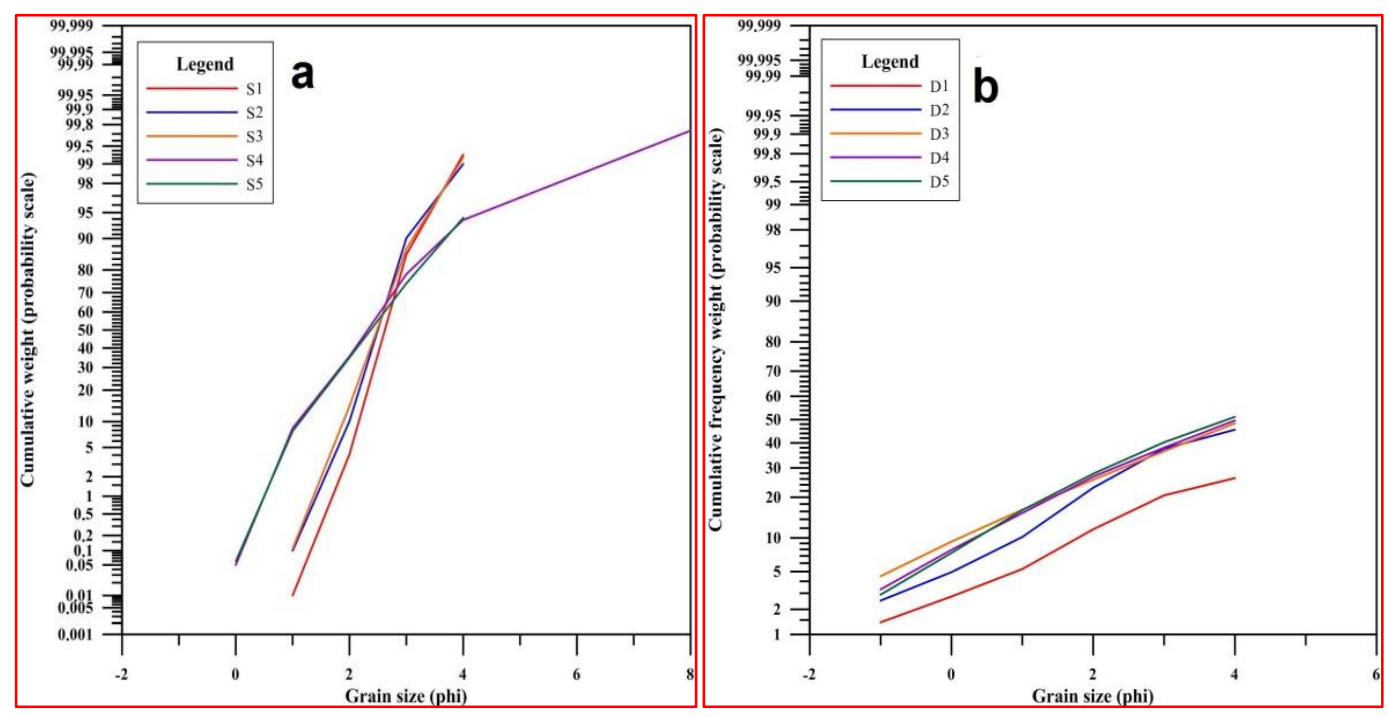

Fig. 9. Frequency cumulative curves of a- the sand dunes, and b- the valley sediments.

\subsection{Mineralogy}

\subsection{1. light mineralogical components}

Quartz, calcite, feldspar, and gypsum are the main minerals in the studied samples. Quartz is the major constituents consisting $58.2 \%$; calcite $28.63 \%$, feldspar $9.8 \%$, and gypsum $3.9 \%$ (Table 3, Figs. 10,11 , and 12).

\subsubsection{Quartz}

The Sharp peaks of quartz reflect the good crystallinity of this mineral. Quartz of the sand dune fields with a mean of $63.13 \%$ is more abundant than that of the valley filling sediments of $53.26 \%$ in a mean.

Table 3. Light minerals (non-clay) percentage and their averages in the study areas.

\begin{tabular}{ccccc}
\hline Sample No. & Quartz $(\%)$ & Calcite $(\%)$ & Feldspar \% & Gypsum $(\%)$ \\
\hline SI & 62.2 & 27.9 & 8.2 & 2.3 \\
S2 & 64.9 & 24 & 7.3 & 4.3 \\
S3 & 62.3 & 25.5 & 10.5 & 2.1 \\
Average & 63.13 & 25.8 & 8.66 & 2.9 \\
D1 & 53 & 31.2 & 11.7 & 4.4 \\
D2 & 52.9 & 30.5 & 12.7 & 4 \\
D3 & 53.9 & 32.7 & 8.4 & 5.1 \\
Average & 53.26 & 31.46 & 10.93 & 4.5
\end{tabular}




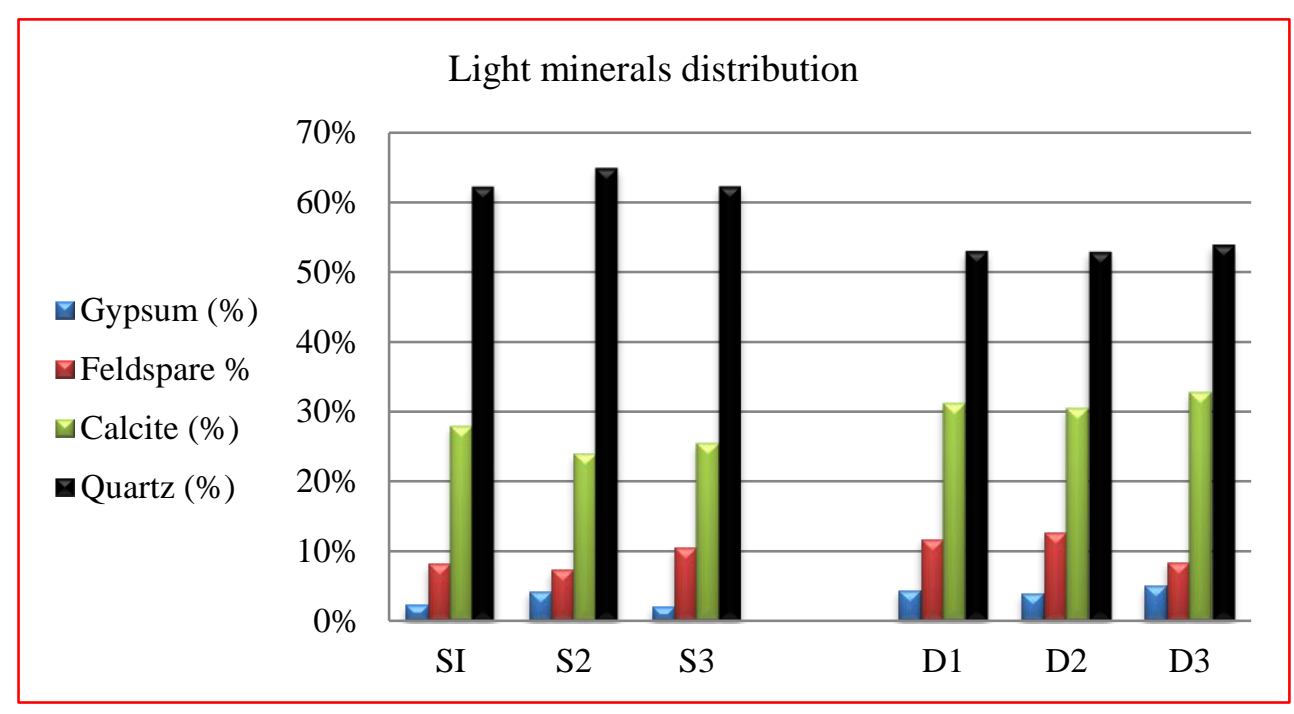

Fig. 10. Light mineral (non-clay minerals) distribution in the current study

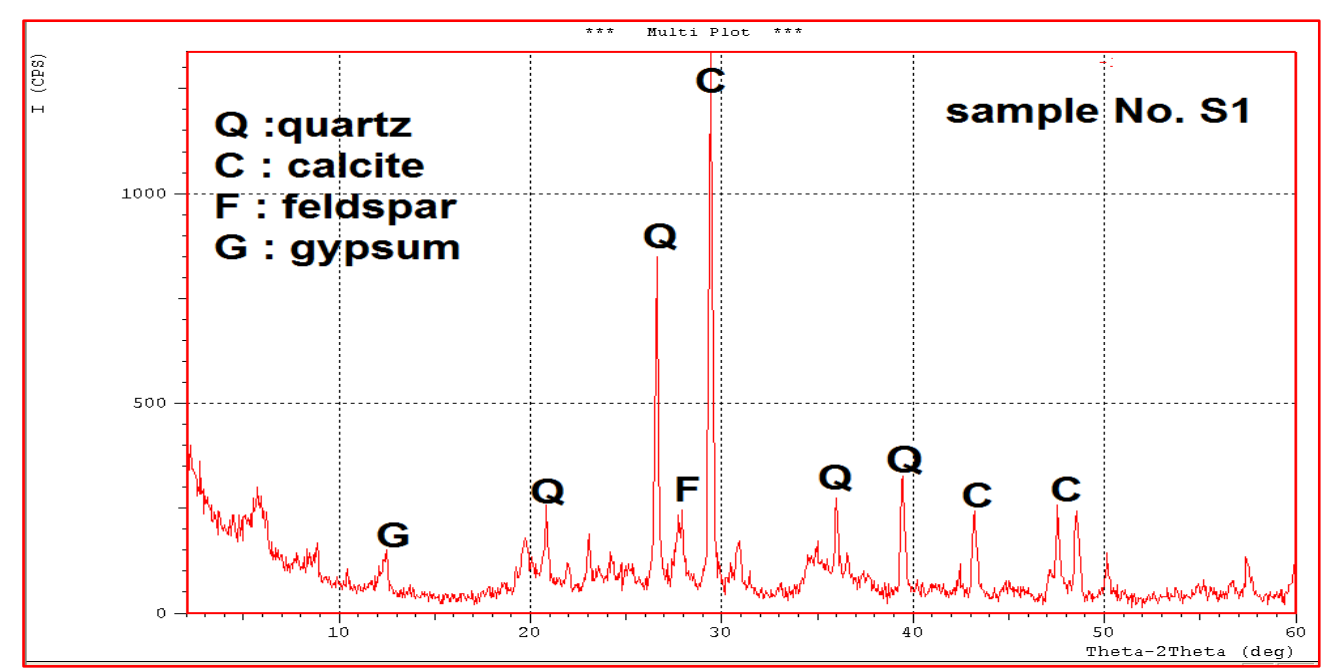

Fig. 11. Diffractogram pattern of XRD represented the dune fields (sample S1).

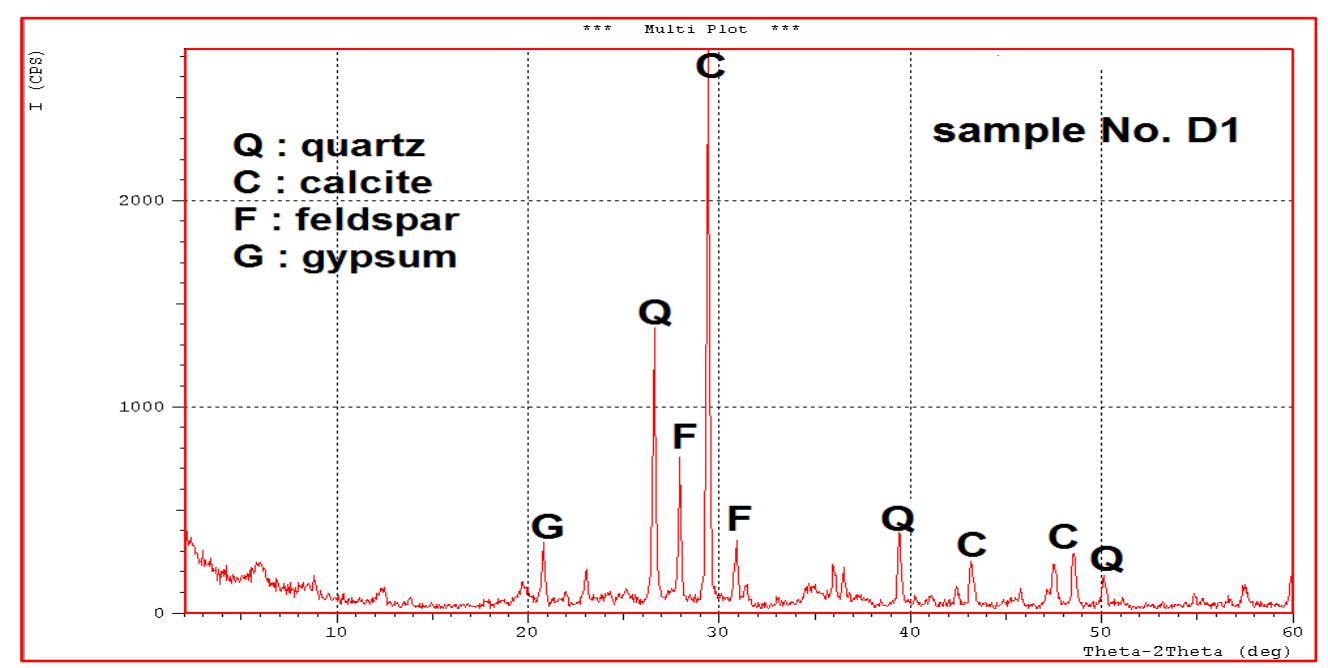

Fig. 12. Diffractogram pattern of XRD represented the valley sediments (sample D1). 
Two types of quartz are observed; mono and polycrystalline quartz. Monocrystalline quartz grains consist of a single crystal (Tucker, 1985). It considered the major quartz type observed in the all studied samples. The mean of monocrystalline quartz in the sand dunes is $52.68 \%$, and its shape is subangular (Plate A-1). In the valley sediment samples, the mean is 35.14\% (Table 4 and Fig. 13), with rounded to subrounded form (Plate B-1). In the sand dune samples, polycrystalline quartz is with an average of $4.54 \%$, and subrounded form (Plate A-2), whereas, in the valley sediments, it is with an average of $4.1 \%$ and subangular shape (Plate B-8).

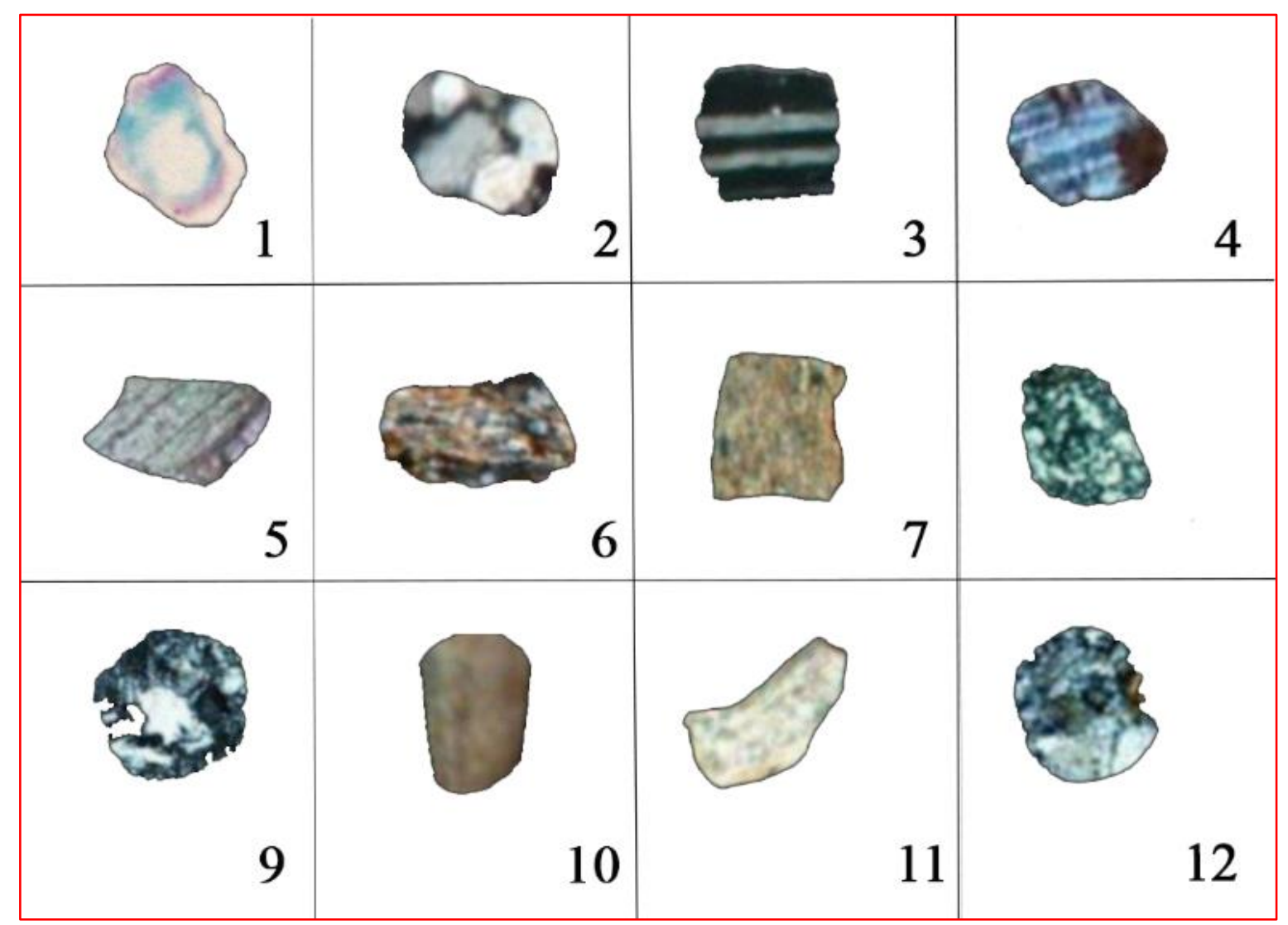

Plate A. Micrographs of the dune field samples in the study area (with scale $0.08 \mathrm{~mm}$ under XPL)

1- Subangular monocrystalline quartz, sample S2.

2- Subrounded polycrystalline quartz, sample S1.

3- Subangular to angular plagioclase with carles bad twinning, sample S1.

4-Subrounded, altered microcline with cross-hatched twinning, sample S3.

5- Angular to subangular altered orthoclase, sample S3.

6-Angular metamorphic rock fragment (schist), sample S2.

7-Angular mudstone rock fragment, sample S4.

8- Rounded to subrounded chert rock fragment, sample S1.

9-Rounded macrochert rock fragment, sample S2.

10-Subangular, elongated carbonate rock fragment, sample S5.

11-Angular evaporate rock fragment, sample S3.

12- Rounded igneous rock fragment, sample $\mathrm{S} 1$. 


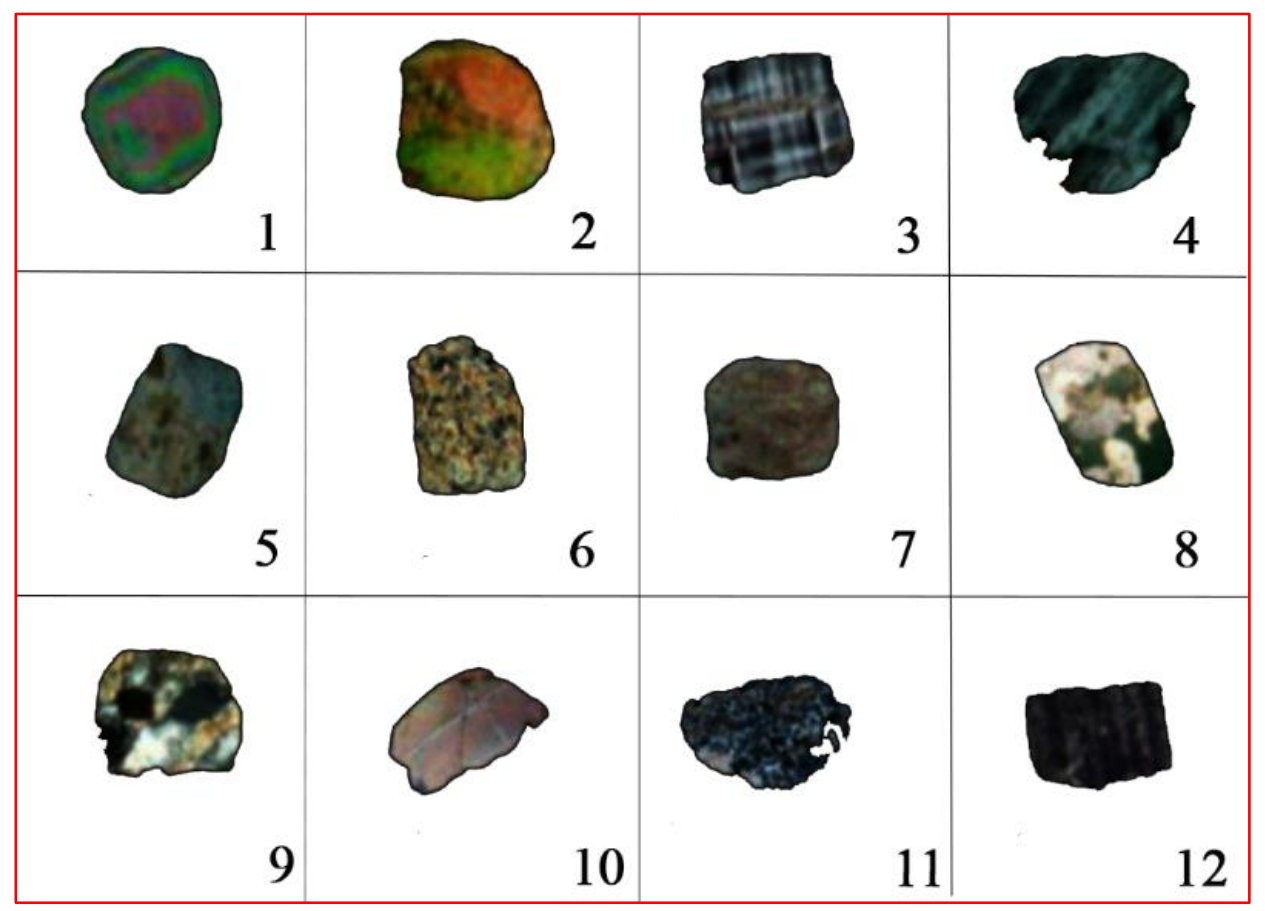

Plate B. Micrographs of the valley sediment samples in the study area (scale of $0.08 \mathrm{~mm}$ under XPL)

1-Rounded to subrounded monocrystalline quartz, sample D2.

2- Rounded to subrounded igneous rock fragment, sample D3.

3- Angular microcline with cross-hatched twinning, sample D1.

4- Subrounded plagioclase with carles bad twinning, sample D2.

5- Angular, altered orthoclase, sample D4.

6- Angular, high altered orthoclase, sample D1.

7- Subangular mudstone rock fragment, sample D5.

8- Subangular polycrystalline quartz, sample D2.

9- Subangular igneous rock fragment, sample D5.

10- Subangular evaporate rock fragment, sample D3.

11- Subrounded chert rock fragment, sample D4.

12- Angular, altered plagioclase, sample D4.

\subsubsection{Calcite}

The mean ratio of calcite is $25.8 \%$ in the sand dunes fields area, whereas $31.46 \%$ in the valley sediments. (Table 3 and Figs. 10, 11, and 12).

\subsubsection{Carbonate and other rock fragments}

From the polarized microscopic observations, the carbonate rock fragments (calcite) form the main components of sedimentary rock fragments and other rock types. The means of them are $13.88 \%$ and $21.16 \%$ in the sand dunes and valley sediments, respectively (Table 4 and Fig. 13). The shape is subangular and elongated in the sand dunes (Plate A-10). Igneous rock fragments are with a mean of $2.76 \%$ in the sand dunes, with rounded form (Plate A-11), and $3.1 \%$ in the valley sediments with subrounded to subangular shape (Plate B -2 and B-9). Metamorphic rock fragments in the sand dune fields have a mean of $2.78 \%$, and angular shape grains (Plate A-8), while in the valley filling sediments is with a mean of $2.62 \%$. Mudstone rock fragments in the sand dunes are of a mean $3.5 \%$, and angular 
shape (Plate A-7), whereas the mean of the valley sediments is $6.94 \%$, and subangular shape (Plate B 7) (Table 4 and Fig. 13).

\subsubsection{Feldspar}

This mineral is present in the dune fields' samples with an average of $8.66 \%$, and in the valley sediments with an average of 10.9\% (Table 3 and Figs. 10, 11, and 12). Petrographically, feldspars are of $3.8 \%$ in average for the sand dune samples. The average of potash feldspar proportion is $5.68 \%$ (Table 4 and Fig. 13).The recognized shapes are altered subrounded for microcline with cross-hatched twining, and altered angular to subangular for orthoclase (Plate A- 4 and A-5). Plagioclase is with a mean of $2.45 \%$. Its form is subangular to angular with carles bad twining (Plate A-3). In the valley filling sediments, feldspar concentration records an average of $4.62 \%$. The average of potash feldspar is $6.32 \%$, while the shapes angular for microcline and altered to angular for orthoclase (Plate B-3, B-5 and B-6). Plagioclase is with an average of $2.92 \%$, and subrounded to angular with carles bad twining shape (Plate B-4 and B-12).

Table 4. Mineralogical constituents' percentage of the sand grains in the dune fields and the valley sediments areas

\begin{tabular}{lcccccc}
\hline $\begin{array}{l}\text { Mineral } \\
\text { components }\end{array}$ & S1 \% & S2 \% & S3 \% & S4 \% & S5 \% & Average \\
\hline Mono Quartz & 53.3 & 52.3 & 53.4 & 53 & 51.40 & 52.68 \\
Poly Quartz & 4.1 & 4.6 & 4.9 & 4 & 5.10 & 4.54 \\
Potash field & 6.2 & 7.1 & 5.7 & 4.63 & 5.10 & 5.746 \\
Plagioclase & 2.3 & 1.8 & 3.1 & 2.77 & 2.30 & 2.454 \\
Carbonate R.F. & 14.5 & 13 & 12 & 14.3 & 15.60 & 13.88 \\
Chert R.F & 6.5 & 6.4 & 6.49 & 6.7 & 8.20 & 6.858 \\
Igneous R.F & 2.5 & 2.8 & 2.1 & 3.5 & 2.9 & 2.825 \\
Metamorphic R.F & 1.9 & 1.8 & 3.8 & 2.1 & 4.3 & 2.78 \\
Evaporates & 5.5 & 5.8 & 5.4 & 5.1 & 2.1 & 4.78 \\
Mudstone & 3.2 & 4.4 & 3.11 & 3.9 & 3 & 3.522 \\
\hline & & The valley sediment samples & & \\
Mineral & & $\mathbf{D 2} \%$ & $\mathbf{D 3 \%}$ & $\mathbf{D 4} \%$ & $\mathbf{D 5} \%$ & Average \\
components & D1\% & & & & & \\
\hline Mono Quartz & 35.5 & 32.5 & 36.1 & 36.1 & 36.1 & 35.26 \\
Poly Quartz & 4 & 4.2 & 4.3 & 4.3 & 4.3 & 4.22 \\
Potash field & 5.8 & 6.3 & 6.8 & 6.8 & 6.8 & 6.5 \\
Plagioclase & 3.1 & 2.9 & 2.4 & 2.4 & 2.4 & 2.64 \\
Carbonate R.F & 19.8 & 22.3 & 21.5 & 21.5 & 21.5 & 21.32 \\
Chert R.F & 11.9 & 11 & 10.5 & 10.5 & 10.5 & 10.88 \\
Igneous R.F & 3.3 & 3.6 & 2.9 & 2.9 & 2.9 & 3.12 \\
Metamorphic R.F & 2.6 & 2.8 & 2.6 & 2.6 & 2.6 & 2.64 \\
Evaporates & 6.2 & 7.3 & 6.5 & 6.5 & 6.5 & 6.6 \\
Mudstone & 7.8 & 7.1 & 6.4 & 6.4 & 6.4 & 6.575 \\
\hline
\end{tabular}




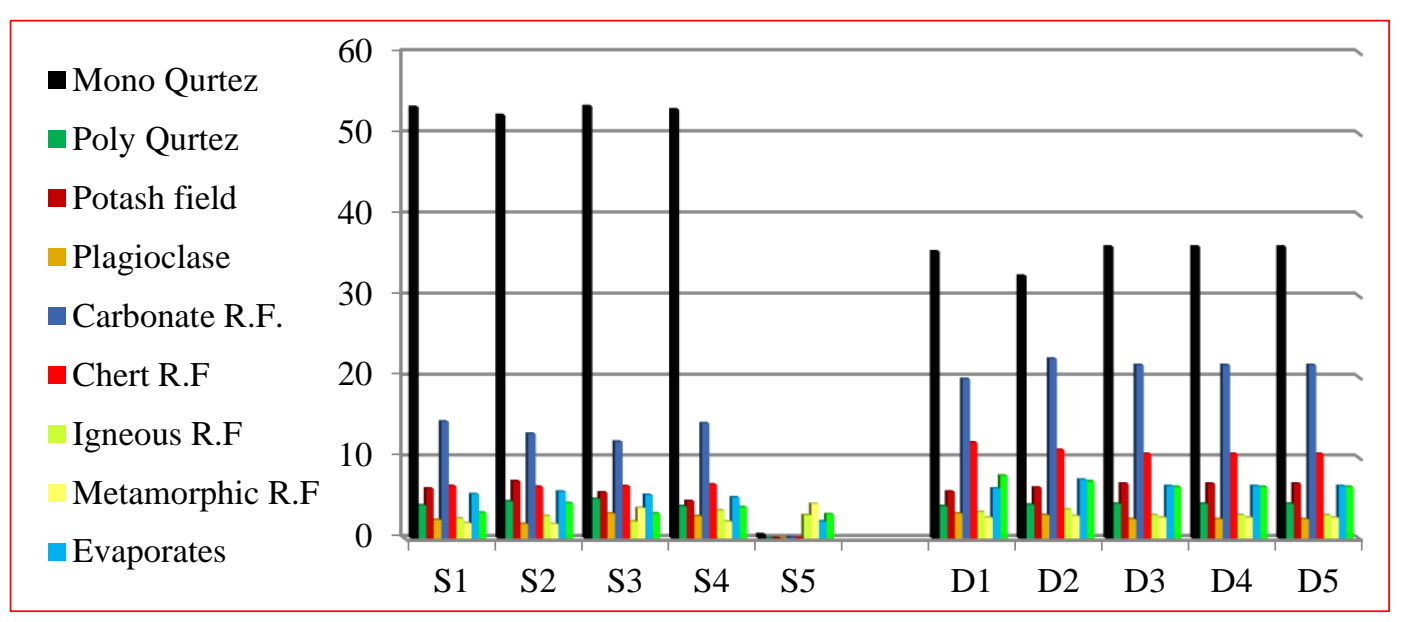

Fig. 13. The distribution of the light minerals in the selected samples of the dune fields and the valley sediments

\subsubsection{Evaporates}

XRD diffractogram patterns and their semi-quantitative explain that gypsum recorded an average of $3.7 \%$ in both investigated areas (Table 3 and Figs. 10, 11, and 12). On based of microscopic investigations, the mean proportion of evaporate rock fragments is $4.78 \%$ in the dune fields, and its form is angular (Plate A-11). The valley filling sediments recorded 6.0\% of an average (Table 4 and Fig. 13), and the shape of grains is subangular (Plate B-10). According to the ternary of Folk (1980), the classification of sand is litharenite (Fig. 14).

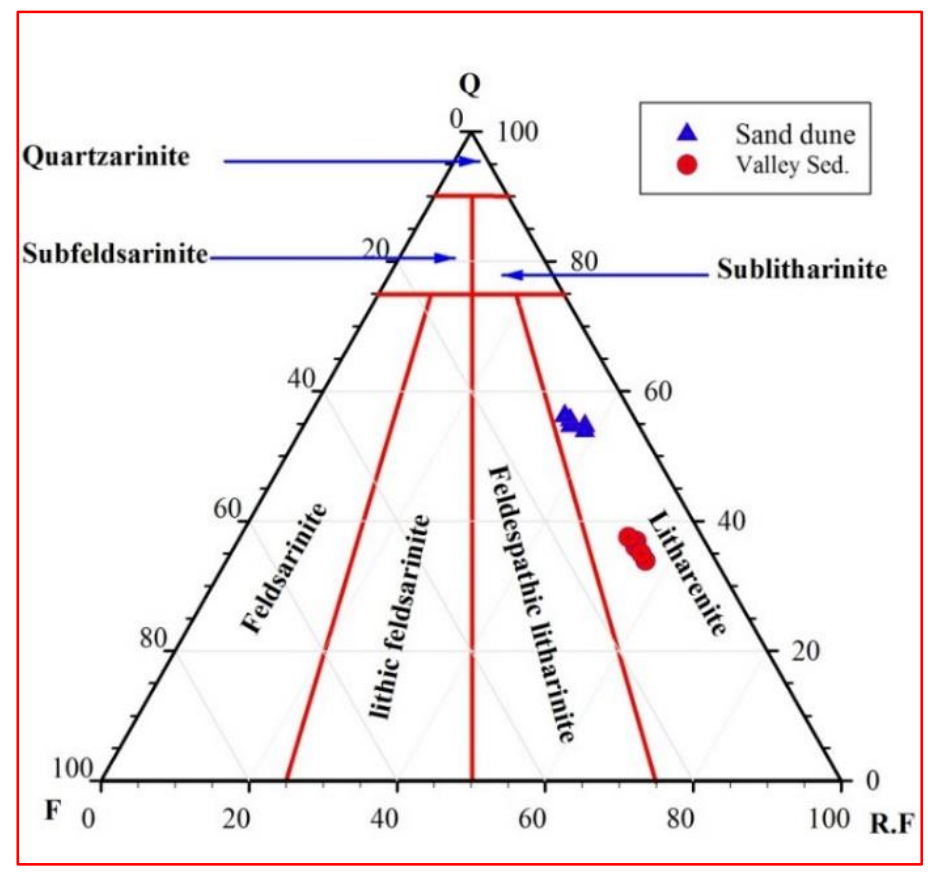

Fig. 14. Ternary Sand Classification Of The Study Areas According To Folk (1980)

\subsubsection{Petrogenesis}

The sand samples of the present study are plotted on the QFL diagram (quartz-feldspar-lithic rock fragments) suggested by Dickinson and Suczek (1983), as shown in Fig. 15. This plot shows that the studied sands fall in quartzose recycled field for the sand dunes, and transitional recycled field for the valley sediments. 


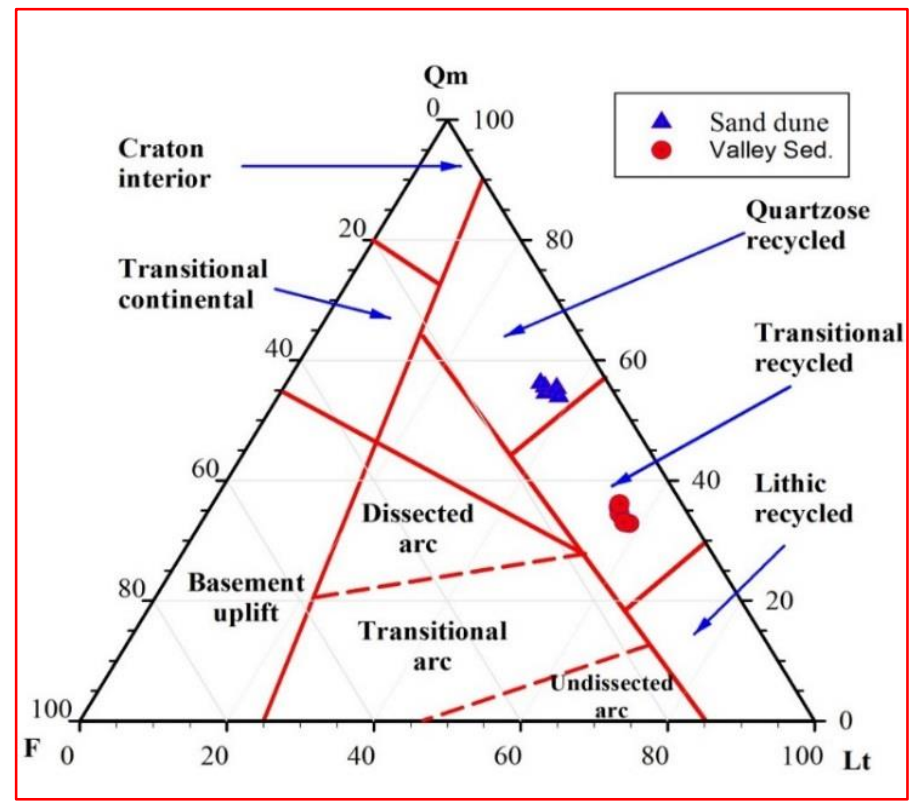

Fig. 15. Tectonic discrimination fields (after Dickinson and Suczek 1983) on QFL ternary diagram showing sand modal of the current study, where $\mathrm{Qm}=$ quartz, $\mathrm{F}=$ feldspar and $\mathrm{Lt}=$ lithic fragments.

\subsubsection{Maturity}

The maturity mineralogical index (MMI) is determined for the studied sandy sediments. It can be calculated according to the following equation:

$$
\text { MMI }=\mathrm{Q}+\mathrm{Ch} / \mathrm{F}+\mathrm{RF}(\text { Pettijohn, 1957) }
$$

Where $\mathrm{Q}=$ quartz, $\mathrm{Ch}=\mathrm{Chert}, \mathrm{F}=$ Feldspar, $\mathrm{RF}=$ Rock fragments. MMI with an average of 52.7 ranging from 50.7 to 54.8 (Table 5), indicated that the sediments in both study areas are immature.

Table 5. Data of mineral maturity index (MMI) in the investigated areas

\begin{tabular}{cc}
\hline Sample No. & MMI \\
\hline S1 2 & 51.04 \\
S2 31.24 \\
S4 & 50.7 \\
S5 & 51.3 \\
Average & 51.52 \\
D1 & 51.16 \\
D2 & 54.2 \\
D3 & 54 \\
D4 & 53.8 \\
D5 & 54.8 \\
Average & 54.39 \\
\hline
\end{tabular}

\section{Discussion}

Grain size is one of the most fundamental properties of sediments. Its distributions provide important clues of sediment provenance, transport history and depositional conditions (Sierra et al., 2013; Al-Khalf and Al-Saad, 2019). Quartz is a resistant mineral to weathering processes during long- 
distance transportation (Tucker, 1991). The different quantities of quartz in both study areas attributed to a high amount of sand fractions, as well as multi rework operations of aerial transportation and sedimentation in the sand dunes compared to the valley filling sediments.Decrease of quartz in the valley sediments may related to the sand grain sizes, which are commonly fine due to abundance of clay- sized particles as indicated by high mud content in these sediments (Table 2, Figs. 4, 5, and 6). The grain size analysis revealed that aeolian dynamic action of the sand dunes is higher than hydrodynamic one in the valley filling sediments.

The high abundance of calcite and carbonate rock fragments in the valley filling sediments is due to presence of carbonate-rich formations crossed by valleys, such as Euphrates and Dammam formations. Moreover, the sand dune sediments suffered multi recycled of weathering and transportation that caused reducing in unstable calcite and carbonate rock fragments. These processes also effect on concentration of other rock fragments constituent in the sand dunes. Furthermore, the shallow, wide, and relatively arid valleys in the study area coinciding with low hydrodynamic currents are the result to low weathering and erosion degrees of these lithic fragments.In other word, evaporite, igneos, and metamorphic rock fragments are ,relatively more quantity in the valley sediments rather than in the sand dunes. Feldspar is represented in a low concentration in the studied samples that attributed to its low resistance to weathering processes than quartz mineral. However, orthoclase feldspars are more stable in weathering conditions than plagioclase (James et al., 1981). With a ternary diagram of the QFL diagram ( Dickinson and Suczek, 1983), the petrogenesis of the studied sediments may indicate to predominance of continental origin (Fig. 15) derived from recycled orogenic activity (Tucker, 2011).

\section{Conclusions}

- Sand is the predominant fractions in the sand dunes, and the texture is silty sand, whereas the clay is the major component in the valley filling sediments.

- Graphically, the sand dunes are recognized by unimodal mode and dominant of very fine sand particles. The same is recorded for the valley sediments with a predominance of clay constituents.

- The size fractions of the valley sediments are, relatively more rather than fractions in the sand dunes.

- Mineral compositions and petrographical investigation results show that the various minerals of the sediments in the sand dunes suffered mechanical weathering more than in the valley filling deposits.

- The classification of the mineralogical composition is litharenite indicating immature sediments.

- The petrogenesis of the sands shows a quartzose recycled field for the sand dune fields and a transitional recycled field for the valley sediments. These sediments are of continental origin derived from recycled orogenic activities.

- The provenace of the study sediments may be believed from contenental Arabian Shield (Saudi Arabia).

\section{Acknowledgements}

The authors very grateful to the staff of laboratories Iraq Geological Survey for their helps. They are very grateful to Dr. Prof. Salih M. Awadh, Mr. Samir R. Hijab the Editor in Chief the Secretary of Journal and the Technical Editors for their great efforts and valuable comments.

\section{References}

Abdul-Ameer, A., 2012. A Geomorphological Study of Dune Fields and their Environmental Effects at AlMuthanna Governorate-Iraq, Unpub, PhD. Thesis, University of Baghdad, Iraq. 164 pp. 
Al-Janabi, K. Z. Ali, A. J., Al-Taie, A., and Jack, T. J., 1988. Origin and nature of sand dunes in the alluvial planes southern Iraq. Journal of Aid Environment. 14, 27-34.

Al-Khalf, N. A., Al-Saad, H. A., 2019. Mineralogy and geochemistry of recent sediments in Basrah, southern Iraq. Iraqi Geological Journal, 52 (1), 40- 52.

Allen, T., 1981. Particle Size Measurement, Chapman and Hall, New York. 237pp.

Al-Shakeri, A. J., Jasim, H. K., Abdullah, H. H., Kadhum, A. K., Thwani, H. H., 2017. Uses of sand dunes as building materials, Journal of Science, 58 (4A), 1874-1887.

Boggs, S. J., 1995. Principle of Sedimentology and Stratigraphy. New Jersey, Prentice Hall. 774p.

Buday, T. and Jassim, S. Z., 1987. The Regional geology of Iraq, tectonism, magmatism and metamorphism, GEOSURV, Iraq, 2.

Carver, R. E., 1971. Procedures in Sedimentary Petrology, John Wiley- Chapman Hall, 653pp.

Del Valle, H. F., Rostagno, C. M., Coronato, F. R., Bouza, P. J., and Blanco, P. D., 2008. Sand dune activity in North-Eastern Patagonia. Journal of Arid Environments, 72 (4), 411-422.

Dickinson, W. R., Suczek, C. A., 1983. Plate Tectonics and Sandstone. Earth Science (Geol Rundsch) Interscience, 653-657.

Folk, R. L., 1980. Petrology of Sedimentary Rocks: Texas Austin, Texas Hemphill.

James, W. C., Mack, G. H., Suttner, L. J., 1981. Relative alteration of microcline and sodic plagioclase in semiarid and humid climates. Journal Sedimentology Petrology, 51, 151-164.

Jasim, H. K. 2017. The Sedimentology, Industrial, and Environmental Studies of the Dune Fields in Missan, ThiQar, and Samawa Districts, Southern Iraq, unpublished Ph.D. thesis, Department of Geology, College of Science, University of Baghdad.

Lancaster, N., 1995. Geomorphology of Desert Dunes. Rutledge, New York. 247pp.

Mange, M.A., Maurer, H.F.W., 1992. Heavy minerals in color. London: Minerals, 34, 1-11.

Pettijohn, F. J., 1957. Sedimentary Rocks. Harper and Brothers, New York, 718pp.

Pye, K., Tsoar, H., 2009. Aeolian Sand and Sand dunes, 2nd ed., Library of Congress No. 2008935393, Berlin Springer Press. 458p.

Rasheed, M. J., Al-Ramahi, F. K. M., 2021. Detection of the impact of climate change on desertification and sand dunes formation East of the Tigris River in Salah Al-Din Governorate using remote sensing techniques. Iraqi Geological Journal, 54 (1A), 69-83.

Sagoe, K. M. O., Visher, G. S., 1977. Population breaks in grain size distribution of sand, a theoretical modal: Journal Sedimentology Petrology, 47, 285-310.

Sierra, J. R.; Munoz. J. J., Pons. M. N., 2013. Influence of sieving time on the efficiency and accuracy of grainsize analysis of beach and dune sands. Sedimentology, 60, 1484-1497.

Sissakian, V. K., Al-Ansari, N., Knutson, A., 2013. Sand an Iraq. Natural Science, 5 (10), 1084-1094.

Thorez, J., 1976. Practical Clay Identification of Clay Minerals. (E. G. L. Disan, Ed.), 92pp.

Tucker, M. E., 1985. Sedimentary Petrology: An Introduction, 4th ed., Oxford: Blackwell. 252pp.

Tucker, M. E., (edits). 1988. Techniques in Sedimentology. Black Well. Oxford. 394pp.

Tucker, M. E., 1991. Sedimentary Petrology, An Introduction. To Origin of Sedimentary Rocks, 2nd ed. Black Well Scientific Lid., 560pp.

Tucker, M. E., 2001. Sedimentary Petrology: An Introduction to the Origin of Sedimentary Rocks. 3th ed., Blackwell Scientific Publications. UK, 291pp.

Watson, J. M., 1997. Desert Features. USGS.

Wentworth, C., 1922. A scale of grade and class term for clastic sediments: Journal of Geology, 30, 377-392. 